\title{
Gendered brokerage and firm performance - an interlock analysis of the UK
}

\begin{tabular}{|r|l|}
\hline Journal: & International Journal of Productivity and Performance Management \\
\hline Manuscript ID & IJPPM-01-2021-0022.R1 \\
\hline Manuscript Type: & Standard Paper \\
\hline Keywords: & $\begin{array}{l}\text { Interlocking directorates, Gender, Brokerage, Resource dependency } \\
\text { theory, Networks }\end{array}$ \\
\hline \multicolumn{2}{|l}{} \\
\hline
\end{tabular}

\section{SCHOLARONE \\ Manuscripts}




\title{
Gendered brokerage and firm performance - an interlock analysis of the UK
}

\begin{abstract}
Purpose: Corporate success depends partially on the quality of knowledge accessible to the executive board. One route of access to such knowledge is the appointment of directors who already hold directorships with prominent other corporate actors. Such director appointments provide interlocks to a corporate knowledge ecosystem (Haunschild and Beckman, 1998). The purpose of this paper is to examine how linkages between companies belonging to different sectors impact firm performance and to examine how linkages created by female directors, as opposed to male directors, shape performance.
\end{abstract}

Design/methodology/approach: This paper investigates the interlocks created between UK FTSE 350 companies from 2010 to 2018 . It draws on network analysis to map the roles that male and female directors play in linking firms with varying sector classifications. The paper provides an examination of the impact of these roles on firm performance, through a panel data regression analysis.

Findings: This paper finds that there is an increase of inter-industry brokers over the period, and that men are still dominant in both the network and creating inter-industry ties amongst companies. However, the role of women in establishing these ties appears to be changing, and women are more important when it comes to create inter-industry ties among key economic sectors.

Originality: This paper provides a novel approach to examine the interplay between gendered inter (and intra) sectoral linkages and firm performance. It provides an original application of the twomode brokerage analysis framework proposed in Jasny and Lubell (2015). 
Keywords: Interlocking directorates; gender; brokerage; networks; resource dependency theory

\section{Introduction}

Interlocking directorates happen when a director who is affiliated with one company also sits on the board of directors of another. This is a multilevel decision involving the director who is taking a new appointment, the appointing company board, as well as all other corporations he/she is affiliated with. Over the years, interlocks are no longer seen as a controlling mechanism but as a knowledge transfer mechanism. This has been associated to resource dependency theory (Pfeffer and Salancik, 1978), where interlocks can be seen as a source of information, reducing uncertainty for companies.

We construct this work on the assumption that interlocks indeed act as transfer mechanisms between companies. We investigate the gender composition of the boards when interlocks can facilitate a knowledge transfer mechanism between companies belonging to various sectors. The study is done on UK FTSE 350 companies, and we look at their boards of directors from 2010 to 2018. The year 2010 marks an important milestone for efforts to achieve gender equality on executive boards. Following the Cadbury Report of 1992 (Cadbury, 1992), the Higgs Review (Higgs, 2003), and the Tyson Report (Tyson, 2003), highlighting underrepresentation of women in executive boards in the UK and the important contributions by women to boards, the $30 \%$ Club was established in August 2010. The 30\% Club is a self-organised group campaigning for an increase in representation of women on public company boards in the UK. Since gender on the executive board is a topic of interest for this study, our data goes back to 2010, and the study focuses on the period after this intervention, the establishment of the $30 \%$ club. 
To achieve the objectives of this study, we make use of Network Analysis concepts. Interlocks can be considered as evidence of inter-organisational network ties, and hence we can construct networks of directors and companies, namely interlocking directorate networks (Heemskerk et al., 2016). Within these networks, we analyse the concept of brokerage. Brokerage is defined as "a relation in which one actor mediates the flow of resources or information between two other actors who are not directly linked" (Fernandez and Gould, 1994, p. 1457). Hence, we use brokerage as a means of understanding the potential of a transfer mechanism of these interlocking directorate networks between 2010 and 2018 .

This paper is structured as follows: the next section provides an overview of the literature on interlocking directorates, focusing on interlocks as a transfer mechanism, the intersection of gender diversity and interlocking directorates, and the use of legislation to promote gender equality on corporate boards. This section concludes with a presentation of the hypotheses that this paper seeks to address. This is followed by a data and methods section, noting the data sources and methodology (including the model specification). A results section follows, detailing the modelling results. In addition, there is a section where we discuss making use of an alternative measure of performance, to act as a robustness check. The final section provides a conclusion, an overview of the main results and limitations, along with avenues for future research.

\section{Literature review $\&$ hypotheses}

Network research initially focused on examining how individuals' embeddedness can have an impact on their behaviour (Granovetter, 1985). Later on, this notion was extended to organisations, for example in the works of Burt (1982), Mizruchi (1992), and Gulati (1995). There are various social and economic relationships by which companies can be interconnected and perceived in network terms, and interlocking directorates is one example of such relationships. 


\subsection{Interlocks as a transfer mechanism}

The research on interlocking directorates suggest different paradigms as explanations for why interlocks are created (Smith and Sarabi, 2021a). Over the years, the idea of interlocks as a controlling mechanism has changed into interlocks as a transfer mechanism. Numerous theoretical frameworks have emerged to explain the reasons behind interlocks formation: management control, financial control, class hegemony, and resource dependency (Burt, 1983; David and Westerhuis, 2014; DiMaggio and Powell, 1983; Hillman and Dalziel, 2003; Mizruchi, 1992; Selznick, 2011; Sheard, 1993, 1993; Zajac, 1988).

The formation of interlocks can be investigated within the aforementioned paradigms and from the perspective of both directors and companies. Stokman et al. (1988) and Zajac (1988) have both studied interlock formations from the perspective of individuals, rather than as inter-organisational relationships. Useem (1986) suggests that directors sitting on multiple boards take advantage of the "business scan"; they expand their range of relationships and experience by being on multiple boards, which in turn means more board memberships for them. As Davis (1993) states in his study, heavily interlocked directors are more prone to be chosen for new board positions. Interlocks can also be considered to reflect dense social ties among an elite; the literature suggest that as well as an inter-organisational phenomenon, interlocks can also be viewed as an interclass phenomenon, and ties created for organisational purposes can have an impact on inter-firm political unity (Mizruchi, 1989, 1992).

Focusing on inter-organisational ties, the purpose of director interlocks can be the establishment of control or coordination. Pfeffer and Salancik (1978) argue that interlocks, similar to mergers and acquisitions, are organisational strategies for managing the organisation's relationship with its environment, for instance by tackling competitive uncertainty. This avenue of research, which has 
given rise to the resource dependency paradigm provides a convincing explanation why interlocks are formed (O'Hagan and Green, 2004). But there has been no definite answer for whether reducing uncertainty through interlocks means higher profits for companies. There have been suggestions that interlocks positively affect the profitability of companies (Burt, 1983; Carrington, 1981; Pennings, 1980). But the majority of studies have shown a negative correlation between the two (for example: Fligstein and Brantley, 1992). The literature suggests that these varying results are due to the different types of interlocks that are formed. For instance, Mizruchi and Stearns (1988) demonstrate that in a sample of 22 large US manufacturing companies, those with declining profits in a given year were more likely to appoint a director from a financial institution to their boards. Similar findings, in other business sectors, have been reported by Lang and Lockhart (1990) and (Richardson, 1987).

O’Hagan and Green (2004) argue that the financial control paradigm, discussed by Mintz and Schwartz (1985), should be seen as a separate branch of resource dependency. This paradigm offers more attention to financial companies, suggesting they play a more central role than others in interlocking networks.

Apart from financial resources, interlocks are also seen as opportunities for exchange of knowledge and strategy, and consequently increased knowledge of top decision makers (Beckman and Haunschild, 2002; Carpenter and Westphal, 2001; Lorsch and Young, 1990; Sanders and Tuschke, 2007; Useem, 1986).

In his research, Useem (1982: 210) reports that several directors considered their board appointments as learning tools for "top management education". Directors can also see the consequence of management decisions first hand in their monitoring roles, and hence gain knowledge on how efficient various practices are (Haunschild, 1993). Acquiring knowledge about 
business practice is also facilitated through communication with other directors during meetings. The important aspect to consider here is that the information gained in this way can be highly influential as it originates from trusted sources and is more up to date, compared with information from secondary sources (Davis, 1991; Kahneman et al., 1982; Useem, 1982; Weick, 1995).

Extant literature often discusses these interlocks from the resource-based perspective, examining how these interlocks act as a mechanism for knowledge and advice exchange. Furthermore, when these interlocks occur across sectors, it has been argued that this allows for a wider variety of expertise and resources to be exchange across firms. Hernández-Lara and Gonzales-Bustos (2018) investigate the relationship between interlock ties and firm innovative performance. They find a negative influence of intra-industry ties and a positive influence of extra (or inter) industry ties on innovation. Resource dependency theory argues that inter industry ties provide access to further knowledge and advice, whilst intra industry ties are more closely related to conformist behaviour within an industry.

Furthermore, intra-industry links between firms often attract increased levels of regulatory interest. For example, in the US, this has resulted in the creation of antitrust regulation regarding intra industry (or sector) regulation: the Clayton Antitrust Act of 1914. This act prevents anticompetitive behaviours, specifically prohibiting types of interlock ties (Caiazza et al., 2019). It prohibits interlocking directorates ties between competing companies of a certain size. This act has been followed by several additional statuary provisions aimed at regulating interlocks in specific industries, such as banking and utilities (Baccini and Marroni, 2016). This does not mean that there is no connection between these firms, rather they may not be directly linked. Abdelbadie and Salama (2019) applied a resourced based perspective to examine the impact of indirect interlock ties on US banking practices. Indirect interlock ties are of particular importance in the US, in the 
context of antitrust regulation. The European case contrasts with this, as European antitrust legislation does not directly tackle the issue of director interlocks; it does not follow the approach of the Clayton Act in the USA (Petersen, 2016). In the UK, company law is based in common law, and therefore does not regulate in detail the specific roles and structure of corporate boards; rather there is a practice of self-regulation (Johanson and Østergren, 2010).

Although the resource dependency theory is often utilised to examine director interlocks, numerous other theoretical frameworks have been utilised to better understand corporate governance and interlock patterns. For instance, agency theory has been frequently applied to explain the negative relationship between firm performance and interlockings directorates. Agency theory would suggest that director with multiple appointments are too busy to be effective monitors within the firm, rather they act as a conduit for knowledge and advice between firms (Ferris et al., 2003; Kaczmarek et al., 2014).

\subsection{Gender diversity \& interlocking directorates}

What has been discussed so far, from the resource dependency paradigm and associated studies, emphasises primarily on directors and their characteristics. Their networks and connections to other directors can be seen as an attribute and the source of their information and knowledge, which they disseminate through interlocks. But we should also consider how the gender of these directors, more specifically interlocking directors, can act as an important resource which may be utilised by companies. Hence, women representation on corporate boards has become an important issue, extensively discussed by scholars (for example, see Buallay et al., 2020; Burke, 1997; Burke and Mattis, 2013; Drago and Aliberti, 2019; Kirsch, 2018; Nguyen et al., 2020; O’Hagan, 2017).

The literature on board gender diversity is somewhat focused on identifying barriers to the appointment of women to corporate boards (for example Burke, 1997; Singh and Vinnicombe, 
2004). But a different approach is to investigate how gender diversity can contribute to board dynamics, processes, and performance, ultimately being translated into firm performance (Adams and Ferreira, 2009; Garanina and Muravyev, 2020; Green and Homroy, 2018; Gulamhussen and Santa, 2015; Isidro and Sobral, 2015; Lückerath-Rovers, 2013; Singh et al., 2008). These studies have suggested that boards with more women experience more debates, and women can have significant impact on decision making processes in the boardroom. Women can also bring with them their distinct characteristics to boards which can have an impact on their interactions. For example, Hillman et al. (2002), in a study of US boardrooms, found that women directors tend to have higher degrees, and come from non-business backgrounds.

Ruigrok et al. (2007) suggest that diversity in the boardroom results in an "increased complexity" of interactions between directors, which has yet to be effectively explored in scholarly work. We focus on the role of women since they may represent an increased complexity in boardroom dynamics while their individual characteristics, qualifications, and capabilities, represent a unique resource for companies. Looking more specifically at women directors participating in interlocks and taking the resource dependency paradigm, O'Hagan (2017) suggests that women interlocks have greater impact on corporate performance than simply larger women representation on boards. This is an interesting insight which supports the idea that diversity on interlocks is also beneficial for companies.

Other areas of the literature have found no effect on performance as a result of increased female representation on boards of directors (Marinova et al., 2016; Mazzotta et al., 2017), or in some cases a negative impact. For instance, Smith et al. (2006) note that increased gender diversity on boards of directors could potentially result in an ineffective board, that takes longer to make decisions, as conflicts can occur more easily on diverse boards. This can increase coordination 
costs and results in a negative impact on financial performance. Ararat and Yurtoglu (2020) find that female representation only predicts increased firm value when female directors have active roles, such as committee memberships in their study on firms in Turkey; they note that otherwise there is no evidence of an impact of female representation on firm performance.

Extant literature has also examined the demographics (nationality and business education) and behaviours of female directors compared to their male counterparts (Bennouri et al., 2018), in particular in relation to risk taking behaviours (Abou-El-Sood, 2021; Belaounia et al., 2020; Lenard et al., 2014; Mastella et al., 2021). Much of the literature suggests that female directors are more risk adverse, and less competition driven (compared to male directors), resulting in less risk-taking behaviour. This is exemplified by Kroes (2009), when she suggest that if it was Lehman Sisters instead of Lehman Brothers that the crisis would not have happened the way it did. Ryan and Haslam (2007) note that women directors often outperform male directors on tasks with increased risk. However, Croson and Gneezy (2009) argue that whilst the notion that women are more risk adverse could apply to the general population, in managerial positions, differences in risk taking behaviour are smaller and even non-existent. Zalata et al. (2019) tackle the question of whether female CEOs' risk and ethical behaviour actually differ compared to their male counterparts in a study of the US corporate system. They find that female CEOs are more risk-averse than male CEOs; yet this is not because they are more sensitive to ethical issues. Rigolini et al. (2021) provide a subsequent analysis of female CEO appointments; in their analysis of Norwegian firms, they find that the appointment of a female CEO, following a male CEO, tends to reduce the level of risk of the firm. 


\subsection{Board gender diversity \& quotas}

The interventions that have occurred to increase the number of women on boards and diversify the compositions of boards justify their cause by arguing that diversified boards mean better performance for companies. For example, the European Commission in its 2012 proposal for the directive set to improve gender balance in listed companies (among non-executive directors) states that: "The proposed Directive will lead to breaking down the barriers that women face when aiming for board positions and to improved corporate governance, as well as enhanced company performance.” (European Commission, 2012, p. 5). Policy makers aiming for diversified boards make use of consultancy studies suggesting that companies with boardroom diversity perform better than others (Catalyst, 2007; Credit Suisse, 2012; McKinsey, 2007). But it is also suggested that addressing the question whether diversified boards improve performance needs more academic research, focusing on three issues: data limitations, selection, and casual inference (Adams, 2016).

The approach by policy makers to achieve gender diversity on boards of directors varies from country to country (Mokadem and Muwafak, 2020). There is a number of legislative approaches used by policy makers, ranging from hard binding laws, soft non-binding laws, to voluntary approaches. An example of a hard binding law to achieve a gender balance on boards is the introduction of quotas; however, quotas are often a controversial issue in many countries. One of the most prominent examples of a hard binding law was the introduction of quotas in Norway in 2003 , to ensure $40 \%$ of directors on the boards of publicly listed firms are the underrepresented sex (Strøm, 2015). Non-compliance with this law would result in harsh sanctions, including heavy fines and even the dissolution of the firm. Hard binding legislative approaches can also be observed in Italy, Germany, France, and Belgium (Rebérioux and Roudaut, 2019; Seierstad and Huse, 2017). 
A soft non-binding legislative approach is observed in Spain, where there are limited to no sanctions for non-compliance. Many argue that these soft law approaches lead to minimal improvement in gender diversity, and often only result in short term results (de Cabo et al., 2019; Conde-Ruiz et al., 2019; Piscopo and Clark Muntean, 2018).

A further approach to promote gender diversity on corporate boards is the voluntary (or selfregulation) option. For this approach governance codes, often with a comply or explain element, are utilised to promote gender diversity in the boardroom. There is often debate whether this approach can be truly effective, especially without any legislative action or enforcement (MensiKlarbach et al., 2019). An example of an institutional environment pursuing the voluntary and selfregulation approach is the UK. Whether there are hard, soft, or voluntary measures in place to encourage gender equality depends on the institutional and cultural environment (Carrasco et al., 2015).

It is important to note that the introduction of quotas in Norway was seen to result in a small selection of female directors with a high number of directorships, which have been referred to as "golden skirts" (Huse, 2012; Seierstad and Opsahl, 2011). These golden skirt directors represent busy or over boarded female directors. There has been much debate on the impact of directors that are busy or over boarded on firm performance (Cashman et al., 2012; Ferris et al., 2003). Many argue that directors with several appointments are ineffective having too many commitments, and that this especially impacts their monitoring role (Fich and Shivdasani, 2012; Hamdan, 2018). Others argue that whilst these busy directors are not effective monitors, they often have extensive contacts and connections, making them an excellent source of knowledge and advice on the board of directors (Field et al., 2013; Harris and Shimizu, 2004). 
In the UK, the regulatory body, the Financial Reporting Council (FRC), which sets the UK's Corporate Governance and Stewardship Codes is cautioning new regulations regarding over boarded directors, with the aim of encouraging these directors to resign one or more of their positions. The FRC suggests that there should be a clear justification for appointing any busy directors in the company annual report and notes that firms should carefully reflect on these types of appointments (FRC, 2018).

\subsection{Hypotheses}

Overall, the literature discussed clearly suggests that interlocks can be considered as a resource for companies to mitigate uncertainty. It is evident that interlocks are instrumental in providing a mechanism for transfer, whether it is for transfer of resources or knowledge. In this study, we make use of these findings of the literature, and we draw specifically on the idea that gender diversity on boards complements interlock resources. We assume here that interlocks contribute to knowledge transfer and proceed to explore changes in brokerage roles for directors on boards in inter- industry relationships.

Therefore, we derive a set of hypotheses from resource dependency theory on how firm sectoral brokerage, and more specifically gendered brokerage, may have an impact on a firm's financial performance. Resource dependency theory argues that a firm (or board) with a high level of linkages to external environments is expected to better access various resources (such as knowledge and advice) (Nicholson and Kiel, 2007). Therefore, we expect that firms that connect to other industries (an external environment) will perform better (in terms of accounting measures of performance).

Hypothesis 1: Companies holding brokerage roles linking to companies belonging to different sectoral classifications will reap performance benefits from these roles. 
Whilst the relationship between female directors and performance is not clear, (as demonstrated in the extant literature), we hypothesise that female brokerage will have positive impact on firm performance. Female directors bring a different set of characteristics to the corporate board, including a different set of linkages and brokerage opportunities compared to male directors (Brown et al., 2002; Singh et al., 2008). Female directors contribute to board diversity, providing the board with a greater range of social capital, which can bridge the board to new resources (Booth-Bell, 2018; Larcker and Tayan, 2013; You et al., 2018). Therefore, brokerage chains involving female directors (or a combination of male and female directors) have the potential to have positive consequences for firm level outcomes (Dunn, 2012; Glass and Cook, 2016).

Hypothesis 2: Gendered brokerage, specifically including female directors, will have increased performance benefits compared to male brokerage.

This hypothesis is tested by making use of a network approach, analysing the interlocking directorates network to identify the brokerage positions male and female directors hold in the UK corporate system.

\section{Data \& Methods}

This study focuses on the case of the UK, an institutional setting that takes a voluntary non-binding approach to gender equality on boards of directors, that is very much centred on the comply or explain approach. This approach is a result of the anti-regulatory sentiments present in the UK, where there is little appetite for interventionist solutions (Doldor, 2017). In the UK, it is interest groups, researchers, and other civil society actors that play key roles in promoting gender diversity. Yet even these diversity campaigns are rarely in favour of the implementation of quotas or hard legislation (Sarabi and Smith, 2021; Seierstad et al., 2017), rather the argument for gender diversity is built around the business case (rather than the ethical consideration as observed in Norway). 
Civil society actors, NGOs and interest groups have been found to be key stakeholders in a range of sustainability issues, including gender diversity, and can shape firm practices in the long term (Sisaye, 2021).

In the UK, compared to other countries which have quota or legislative regimes, there are fewer female directors. Therefore, this study has the potential to inform on whether it is not the level of female directors or diversity on the board that contributes to increased performance, but the roles that female directors can potentially play in linking to new sources of knowledge, advice, and resources. This study has the potential to inform on the business case argument for increased female representation on boards of directors, in an institutional environment that takes a self-regulatory approach.

The firms included in the analysis belong to the UK FTSE 350; these are large and medium sized firms listed on the London Stock Exchange. The time period for this analysis is 2010 to 2018; 2010 represents a milestone year for gender representation on boards of directors in the UK, along with the creation of the $30 \%$ club, a self-organised interest group that campaigns for increased female representation on FTSE boards of directors. Initially the $30 \%$ club campaigned for the top 100 firms in the UK to have at least $30 \%$ female representation on its board of directors. In 2015 , when this target was in sight, the group set two new objectives (Sarabi and Smith, 2021). Firstly, they expanded the $30 \%$ representation goal to the top 350 firms in the UK (the FTSE 350), moving beyond the top 100 (FTSE 100). The second goal was for 30\% female representation in senior management within FTSE 100 companies aligning with recommendations set out in Davies Review. This study examines the period of 2010 to 2018, capturing the establishment of the interest group, and when it revised its campaign objectives. 
The company level data is collected from a combination of Companies House (extracted programmatically in R; Smith, 2019) and Bureau van Dijk’s Orbis dataset. Companies House is a British government website that provides information on the directors who sit on the boards of UK firms, such as the start and end dates of their directorships. Companies House also provides firm level data including details on the sector the firm operates in. This data is used to construct the interlocking directorate network, which is a network of directors and firms; directors are linked to firms when they sit on the firm's board of directors. If a director sits on two boards, then these firms will interlock via the director. This network is referred to as a two-mode network; this is a network with two sets of actors, where ties can only occur between sets and not within (Borgatti and Everett, 1997). Metrics derived from this network are utilised to capture the gendered brokerage of a firm, which is subsequently used in a panel data analysis to test the hypotheses presented in this paper. Gender and sector information are utilised to construct these gendered brokerage metrics, where sectors are classified according to a firm's one digit SIC code. The analysis is restricted to the main component of the interlocking directorate network over the time period; that is the firms and directors that are embedded in the largest connected part of the network. We disregard other components as disconnected firms are unable to properly hold a brokerage position. As a result, our sample consists of firms with 2169 firm-year observations.

We make use of a two-mode variant of brokerage chains to examine how firms link to other firms belonging to the same or different sector in the two-mode system. The original brokerage chains were proposed for one-mode network and were developed by Gould and Fernandez (1989); and are therefore referred to as Gould-Fernandez (GF) roles. They proposed five brokerage roles that an actor can hold in a network while linking to actors that are members of the same or different groups in directed one-mode networks: coordinator, representative, gatekeeper, itinerant, and 
liaison. These are presented in figure (1), where the colours represent group membership. The GF roles have been utilised in a wide range of empirical setting to examine brokerage patterns and how actors link between and within different groups; including firm innovation performance research (Belso-Martínez et al., 2015), disaster response studies (Lind et al., 2008), and analysis of international trade (Smith and Sarabi, 2021b). The coordinator role captures when an actor acts as a broker within their own group, indicating that they hold a particular important role for group level coordination. The representative role captures when an actor distributes information or goods outside the group, on behalf of their group. The gatekeeper role captures when an actor distributes outside information or goods to their group. The itinerant role captures when an actor acts as an external broker to another group. The liaison role represents inter group brokerage, linking together actors belonging to different groups.

Insert Figure 1 about here.

However, as the interlocking directorate network is a two-mode network, consisting of two sets of actors (firms and directors), these brokerage roles would only tell us about the linkages between firms belong to various sector classifications, and disregard important information about the directors that link them together (including gender). Therefore we make use of the two-mode extension of the brokerage roles proposed by (Jasny and Lubell, 2015), which are presented in figure (2). The representative and gatekeeper roles are the same in an undirected case, as the only difference between the two is the direction of the ties. Therefore, there are four two-mode GF roles. In figure (2), the circles represent firms and their colours their sector. The squares represent directors, and the direction of the line the director gender. For each role, there are four combinations of directors that link together the various firms. These roles can be read from top to 
bottom of the brokerage chains and include the following director configurations, male-female, female-male, female-female and male-male. There are four configurations for each brokerage role, representing various level of gender heterogeneity in the brokerage position a firm holds linking together firms belonging to different sectors. These brokerage roles are used to test the hypotheses, examining the relationship between firm performance and these types of brokerage. For instance, does male only brokerage has a stronger impact on performance, reinforcing the "old boys" network often observed in the upper echelon of management (Heemskerk and Fennema, 2009).

Insert Figure 2 about here.

Based on the topology we introduced earlier, we count the number of brokerage chains in our networks (interlocking directorate networks for years 2010 to 2018) and classify them based on the type of chain.

Aligned with the work of Jasny and Lubell (2015), we define a two-mode brokerage chain as a situation in which two companies are separated by a shortest path involving two directors and the brokering company. The number of ties between the two companies is four in this case. If the two companies are also otherwise connected through only one director and via two ties, we consider the chain a non-brokered one, and do not include it in the count. Figure (3) depicts the difference between brokered and non-brokered chains. The rationale here is that in the right-hand side structure, the companies can connect to each other via the shortest path between them, i.e., through a single director, and without needing to go through the longer path. By calculating and examining the brokerage chains in our networks, we can determine both the dominant brokerage roles of companies, and consequently sectors, for each year, as well as the diversity of associated directors. 
Insert Figure 3 about here.

Therefore, this analysis is used to construct 16 firm level brokerage metrics (4 for each brokerage role) over the time period. These are then utilised in the panel data analysis to assess the interplay between gendered brokerage and firm performance. An accounting based measure of performance is utilised in this study, Return on Capital Employed (ROCE); an established performance metric used in the analysis of interlocking directorates and performance (Bhatt and Bhattacharya, 2015; Bischoff and Buchwald, 2018).

Additional company level data utilised in this analysis includes, number of employees, total assets, board size, and sector. Hawawini et al. (2003) argue that industry or sector characteristics matter more than firm specific attributes in determining performance, with the exception of dominant leaders in the industry. Number of employees and total assets allow for the control for firm size. Board size has frequently been investigated in relation to firm performance; with a selection of scholarly work suggesting that larger board have a negative impact on firm performance, as they result in poor communication and slow, ineffective decision making (Cheng, 2008; Nguyen et al., 2016; Yermack, 1996). However, others argue that larger boards can offer positive performance benefits, as they are able to better undertake monitoring activities, since the board can offer a wider, more diverse range of opinions (Guest, 2009).

To test the hypotheses presented in this paper, a panel data regression analysis was undertaken, which was implemented in the "plm" R package (Croissant and Millo, 2008). In the panel data regression analysis, the dependent variable was the performance metrics, ROCE. We then specified a number of control variables; these included number of employees (EMP), firm size (as defined as the log of total assets) (ASSETS), board size (BOARD SIZE), and the sector each firm belongs 
to (SECTOR). Resource dependency theory would argue that a larger board should perform better, given it will have greater opportunities to form links to critical resources (Bonn et al., 2004), and potentially additional interlocking opportunities.

To test the impact of the gender brokerage roles on performance, we include the four director configurations for each GF role in a separate model. We take the lag of the brokerage role, examining the number of times a firm played a specific brokerage role in the previous year. We take the lag, as the benefits of network ties are unlikely to be instantaneous, rather it would take some time to have an effect. Additionally, using the lag of the network metrics helps alleviate potential endogeneity effects.

We therefore apply four models, taking the form:

$$
\begin{aligned}
& \operatorname{ROCE}_{t} \\
& =\alpha_{0}+\alpha_{1} \text { EMP }_{t}+\alpha_{2} \text { ASSETS }_{t}+\alpha_{3} \text { SECTOR }_{t}+\alpha_{4} \text { BOARD SIZE }_{t}+\alpha_{5} \\
& \text { MALE - MALE ROLE } E_{t-1}+\alpha_{6} \text { FEMALE - FEMALE ROLE } E_{t-1}+\alpha_{7} F E M A L E \\
& - \text { MALE ROLE } E_{t-1}+\alpha_{8} \text { MALE - FEMALE ROLE } E_{t-1}+\varepsilon
\end{aligned}
$$

\section{Results}

Table (1) presents the descriptive statistics for the firm level attributes; this indicates high levels of variation in firm performance (ROCE). We observe less variation in firm size (as indicated by assets) and number of employees. The average board size is around 9 directors; there has been much debate regarding the ideal board size; in Spain the Olivencia code recommends boards should consist of between 5 and 15 directors (Campbell and Mínguez-Vera, 2008; Fernández- Fernández, 1999); there is no equivalent code for the UK case in relation to the ideal board size. We observe in this case, companies tend to follow this rule, with the average falling within these limits. 
Insert Table 1 about here.

The distribution of the sectors among all companies recorded in our data is presented in table (2), which indicates the proportion of total firms belonging to each sector. We observe that financial sector is the most prominent; this is not surprising, given that interlocks are most prevalent amongst financial firms (Mizruchi, 1996; Shropshire, 2010). Therefore, financial firms are more likely to be present in the main component of the FTSE 350 interlock network over the time period and are potentially more likely to be involved in brokerage chains.

Insert Table 2 about here.

Figure (4) presents the number of firms from each sector holding a specific two-mode GF brokerage role for 2010, 2014 and 2018. Many scholars have noted that the characteristics of an industry or sector, influence the social responsibility of the firm (McWilliams and Siegel, 2000). King et al. (2002) note that the visibility of a sector can influence a firm's corporate social responsibility behaviour, given that firms operating in these sectors will be visible, and more ethical behaviours may have reputational benefits.

In figure (4) we observe that a large number of firms in the finance, insurance, and real estate sector have consistently held brokerage positions, across the various roles. Firms with a coordinator role are chiefly from the finance sector, especially in 2010; in 2014 and 2018 firms from other sectors began to hold these positions, but the majority were still from the finance sector.

For coordinator chains, the majority are male - male, however, we observe an increase in female directors' involvement in these chains in 2018. For itinerant roles, there has been an increase in the number of female-female chains over time, going from only a handful in the wholesale \& retail 
trade sector to a wider variety of sectors in 2010 . The number of chains involving female directors had overtaken the male dominated brokerage chains by 2018, perhaps reflecting the overall trends in the FTSE 350 of increasing female representation (Sarabi and Smith, 2021). Firms belonging to finance, manufacturing (both categories), transportation, communications, electric, gas \& sanitary service sectors have consistently held representative/gatekeeper roles. Similar to the patterns observed for itinerant and coordinator roles, there has been an increase in participation of female director in creating the representative/gatekeeper brokerage chains. This potentially points towards the success of interest groups (such as the $30 \%$ club) in achieving an increase in females playing key roles in the UK corporate system since 2010. For liaison role, the number of female-female chains has drastically increased from 2014 to 2018, with these frequently observed in the financial and manufacturing sectors.

Insert Figure 4 about here.

The results of the panel data analysis are presented in table (3). The chain type refers to the brokerage chain of the two-mode GF role model for each specific model, for instance in the RepGate model the Male-Male role refers to the Male-Male Representative/Gatekeeper GF role.

When implementing the model estimation, a number of robustness checks were carried out. Firstly, to check the issue of multicollinearity, we calculated the variance inflation factor (VIF) for each model. Gujarati et al. (2012) note that an independent variable with a VIF higher than 10 would represent a serious multicollinearity issue. Across all four models, and for all of the independent variables, the VIF was in the acceptable range (less than 2). Therefore, we are confident that our independent variables are not suffering from a serious collinearity problem. A further robustness check that was implemented was for autocorrelation. In panel data or time series analysis, (as 
undertaken in this paper), there is a presupposition of the stability of the series (Hawaj and Buallay, 2021). If the time series is non-stationary, then autocorrelation can occur (Gujarati et al., 2012). In order to check if there is a problem of autocorrelation in the models, the Durbin-Watson (DW) test is employed. If the DW values are within the range of $1.5-2.5$, then this indicates that there is no autocorrelation problem that would impact the results. For the models presented in table (4) the DW values were all within the required range.

The results presented in table (3) indicate that larger firms, as defined by log of assets, are negatively associated with accounting performance (Return on Capital Employed). Board size is not significantly associated with this measure of performance. The sector classification parameters indicate whether firms belonging to the sector perform better than the baseline sector: mining and construction. These results indicate that firm belonging to the personal and supporting business service sector and to a lesser extent the wholesale and retail trade sector, perform better in terms of ROCE. The significant sector results confirm existing findings from the literature, that sector or industry groupings can impact a firm's performance levels (Moura-Leite et al., 2012; Powell, 1996; Short et al., 2007).

Insert Table 3 about here.

The majority of brokerage roles are non-significant, more specifically, the RepresentativeGatekeeper, Itinerant, and Coordinator roles. However, after controlling for firm size, number of employees, and sector classification, the two-mode brokerage roles that have a significant impact on performance are the Liaison roles. In particular, there is a positive liaison effect on performance when there is heterogeneity in the directors creating the brokerage ties. Male-female and femalemale chains have a significant and large, positive effect on performance. Whereas when a firm 
plays a liaison role through same gender ties, there is a negative and (weakly) significant effect on performance. This highlights the need to examine gender patterns and provides support for hypothesis (1) presented in this study: heterogeneity in linkages has positive performance effects. This has mixed support for the second hypothesis, as male-female/female-male chains have a positive impact, indicating potential brokerage benefits of female directors on firm boards. Yet there is a negative female-female effect, suggesting that chains consisting of one gender are unlikely to bring new sources of advice and resources to a firm.

Figure (4) highlights that firms belonging to the finance, manufacturing (both categories) and transportation, communications, electric, gas \& sanitary service sectors, hold more male-female and female-male liaison roles; and therefore, reap performance related benefit from these ties.

\section{Alternative measure of firm performance}

In order to check the robustness of the results presented in this paper, we employ the modelling approach to a further measure of firm performance, Return on Equity (ROE). A range of extant literature uses this profitability ratio as a measure of firm performance (including the works of Bennouri et al., 2018; Lau, 2016; Mashayekhi and Bazaz, 2008). Table (4) presents the modelling results with ROE as the dependent variable. For the control variables, we observe that board size is non-significant, this result is in line with the findings of Zabri et al. (2016) in their analysis of top Malaysian firms. In this analysis, larger firms (according to assets) have a reduced ROE, as indicated by the negative and significant assets variable, this follows a similar pattern as the ROCE modelling results.

Insert Table 4 about here. 
However, a clear point to note here is that the GF brokerage roles are mainly non-significant for the case of ROE, with the exception of the all-male itinerant brokerage chain, which is negative and (weakly) significant. This suggests that a firm acting as an external broker to a different sector through its male directors dampens firm performance, according to this profitability ratio. The other non-significant results suggest that the various brokerage roles do not offer a firm performance advantages in terms of ROE (both in terms of male and female chains). Detthamrong et al., (2017) identify in their analysis of firms in Thailand, that the proportion of female directors on the board is not significantly associated with firm performance, as measured by ROE. The work of Watson (2007) notes in his examination of Australian firms, that network ties have a positive relationship between firm survival and growth, but not ROE. The results presented in table (4) are in line with Watson (2007). Bennouri et al. (2018) offers some explanation for the non-significant brokerage role results observed in table (4), and the difference between ROCE results and ROE results. They find that the effects of different types of director attributes (including gender) on different types of performance (including ROE) was not uniform. Further work could explore the impact of brokerage on other measures of firm performance, more specifically market-based measures of performance, to unpack the interplay between gender, intersectoral linkages, and firm performance.

\section{Discussion \& conclusion}

In this paper, we proposed two hypotheses regarding the impact of gender intersectoral firm ties on performance. The first was that firms with linkages to firms belonging to different sector would benefit from such ties because of gaining access to different knowledge and resources. The second was that gendered brokerage, involving female directors would have a positive effect on firm performance. We tested these hypotheses through the use of metrics derived from social network analysis in a panel data regression, more specifically the use of two mode GF roles proposed by 
(Jasny and Lubell, 2015). The results of the analysis provide support for the first hypothesis, where the only significant effects were for liaison roles, in which firms link to other firms belonging to different sectors (no intra sector linkages). When there was the presence of both male and female directors in these chains, there was a positive effect on performance, suggesting support for hypothesis 1. Furthermore, the roles with intra-sectoral ties were non-significant, indicating no significant relationship with this accounting-based measure of performance (ROCE). This provides support for the resource dependency theory hypothesis, that links to firms belonging to different sectors are more likely to bring new sources of knowledge, advice, and resources, with performance enhancing effects.

However, there is mixed support for the second hypothesis, as indicated by the brokerage chain results in the liaison model given in table (3). In the case of brokerage chains involving both male and female directors, linking to firms belonging to different sector has a positive impact on firm performance. Directors of the same gender linking to firms belonging to different sectors has a negative and weakly significant impact on performance. Haynes and Hillman (2010) note that heterogeneity in boards is key for firm development, and firm with heterogeneous boards are more likely to pursue new strategies. Our findings are in line with Haynes and Hillman (2010), where heterogeneity in brokerage chains, in terms of both industry and gender, is associated with a positive impact on firm performance. This highlights that when examining the impact of firm ties via the interlock network on performance, the characteristics of the directors, especially their gender, should not be neglected as this significantly shapes the benefits a firm reaps from these network ties. This work highlights that when examining the business case for appointing female directors to a firm, it is not only their individual characteristics that contribute to the business case, but also their network ties and potential to provide firm brokerage opportunities. This is particularly 
important when considering the institutional environment of the UK, or any country which employs a voluntary approach, as the business case is often used by interest groups and other campaigners to encourage gender equality on corporate boards.

However, this pattern was only observed for the case of ROCE, and not for the profitability ratio, ROE. For ROE, there was no support for the second hypothesis, where many of the GF brokerage roles had a non-significant (or weakly significant) relationship with ROE. Future work could seek to examine if gendered brokerage has the same impact on other measures of firm performance, more specifically market-based measures of performance. A further avenue for future research would be to explore various other attributes of the directors and how their work history may shape the impact of brokerage on firm performance, rather than focusing solely on directors' gender.

Finally, the results from the ROCE models highlights a need to better understand when heterogeneity in gendered brokerage chains gives rise to an increased firm performance. This suggests there is a need to further examine heterogenous brokerage chains (male-female and female-male liaison chains) in more detail, to identify who the directors and firms are in these key positions. 


\section{References}

Abdelbadie, R.A. and Salama, A. (2019), "Corporate governance and financial stability in US banks: Do indirect interlocks matter?”, Journal of Business Research, Vol. 104, pp. 85105.

Abou-El-Sood, H. (2021), "Board gender diversity, power, and bank risk taking”, International Review of Financial Analysis, Vol. 75, p. 101733.

Adams, R.B. (2016), “Women on boards: The superheroes of tomorrow?”, The Leadership Quarterly, Vol. 27 No. 3, pp. 371-386.

Adams, R.B. and Ferreira, D. (2009), "Women in the boardroom and their impact on governance and performance", Journal of Financial Economics, Vol. 94 No. 2, pp. 291-309.

Ararat, M. and Yurtoglu, B.B. (2020), "Female directors, board committees, and firm performance: Time-series evidence from Turkey”, Emerging Markets Review, p. 100768.

Baccini, A. and Marroni, L. (2016), "Regulation of interlocking directorates in the financial sector: a comparative case study", European Journal of Law and Economics, Vol. 41 No. 2, pp. $431-457$.

Beckman, C.M. and Haunschild, P.R. (2002), "Network learning: The effects of partners' heterogeneity of experience on corporate acquisitions", Administrative Science Quarterly, Vol. 47 No. 1, pp. 92-124.

Belaounia, S., Tao, R. and Zhao, H. (2020), “Gender equality’s impact on female directors' efficacy: A multi-country study”, International Business Review, Vol. 29 No. 5, p. 101737.

Belso-Martínez, J.A., Molina-Morales, F.X. and Martínez-Cháfer, L. (2015), “Contributions of brokerage roles to firms' innovation in a confectionery cluster", Technology Analysis \& Strategic Management, Vol. 27 No. 9, pp. 1014-1030. 
Bennouri, M., Chtioui, T., Nagati, H. and Nekhili, M. (2018), "Female board directorship and firm performance: What really matters?”, Journal of Banking \& Finance, Vol. 88, pp. $267-291$.

Bhatt, R.R. and Bhattacharya, S. (2015), "Do board characteristics impact firm performance? An agency and resource dependency theory perspective", Asia-Pacific Journal of Management Research and Innovation, Vol. 11 No. 4, pp. 274-287.

Bischoff, O. and Buchwald, A. (2018), "Horizontal and Vertical Firm Networks, Corporate Performance and Product Market Competition”, Journal of Industry Competition \& Trade, Vol. 18 No. 1, pp. 25-45.

Bonn, I., Yoshikawa, T. and Phan, P.H. (2004), "Effects of board structure on firm performance: A comparison between Japan and Australia”, Asian Business \& Management, Vol. 3 No. 1 , pp. 105-125.

Booth-Bell, D. (2018), "Social capital as a new board diversity rationale for enhanced corporate governance", Corporate Governance: The International Journal of Business in Society, Vol. 18 No. 3, pp. 425-439.

Borgatti, S.P. and Everett, M.G. (1997), "Network analysis of 2-mode data", Social Networks, Vol. 19 No. 3, pp. 243-269.

Brown, D., Brown, D.L. and Anastasopoulos, V. (2002), "Women on boards: Not just the right thing... but the" bright" thing", Conference Board of Canada.

Buallay, A., Hamdan, R., Barone, E. and Hamdan, A. (2020), “Increasing female participation on boards: Effects on sustainability reporting”, International Journal of Finance \& Economics, pp. 1-14.

Burke, R.J. (1997), “Women directors: selection, acceptance and benefits of board membership", Corporate Governance: An International Review, Vol. 5 No. 3, pp. 118-125. 
Burke, R.J. and Mattis, M.C. (2013), Women on Corporate Boards of Directors: International Challenges and Opportunities, Vol. 14, Springer Science \& Business Media.

Burt, R.S. (1982), Toward a Structural Theory of Action: Network Models of Social Structure, Perception, and Action, Academic Pr.

Burt, R.S. (1983), Corporate Profits and Cooptation: Networks of Market Constraints and Directorate Ties in the American Economy, Academic Press New York.

de Cabo, R.M., Terjesen, S., Escot, L. and Gimeno, R. (2019), “Do 'soft law'board gender quotas work? Evidence from a natural experiment”, European Management Journal, Elsevier, Vol. 37 No. 5, pp. 611-624.

Cadbury, A. (1992), Report of the Committee on the Financial Aspects of Corporate Governance, Vol. 1, Gee.

Caiazza, R., Cannella Jr, A.A., Phan, P.H. and Simoni, M. (2019), “An institutional contingency perspective of interlocking directorates", International Journal of Management Reviews, Vol. 21 No. 3, pp. 277-293.

Campbell, K. and Mínguez-Vera, A. (2008), “Gender Diversity in the Boardroom and Firm Financial Performance”, Journal of Business Ethics, Vol. 83 No. 3, pp. 435-451.

Carpenter, M. and Westphal, J. (2001), “The strategic context of external network ties: Examining the impact of director appointments on board involvement in strategic decision making", Academy of Management Journal, Vol. 44 No. 4, pp. 639-660.

Carrasco, A., Francoeur, C., Labelle, R., Laffarga, J. and Ruiz-Barbadillo, E. (2015), “Appointing Women to Boards: Is There a Cultural Bias?”, Journal of Business Ethics, Vol. 129 No. 2, pp. $429-444$.

Carrington, P.J. (1981), Horizontal Co-Optation through Corporate Interlocks., University of Toronto, Toronto. 
Cashman, G.D., Gillan, S.L. and Jun, C. (2012), “Going overboard? On busy directors and firm value", Journal of Banking \& Finance, Elsevier, Vol. 36 No. 12, pp. 3248-3259.

Catalyst. (2007), The Bottom Line: Corporate Performance and Women's Representation on Boards, Women and Men is US Corporate Leadership. Same workplace, different ....

Cheng, S. (2008), "Board size and the variability of corporate performance", Journal of Financial Economics, Elsevier, Vol. 87 No. 1, pp. 157-176.

Conde-Ruiz, J.I., García, M. and Yáñez, M. (2019), “Does a 'soft’ board gender quotas policy work?", Applied Economic Analysis, Emerald Publishing Limited.

Credit Suisse. (2012), Gender Diversity and Corporate Performance, Credit Suisse, Research Institute.

Croissant, Y. and Millo, G. (2008), "Panel data econometrics in R: The plm package", Journal of Statistical Software, Vol. 27 No. 2, pp. 1-43.

Croson, R. and Gneezy, U. (2009), “Gender Differences in Preferences”, Journal of Economic Literature, Vol. 47 No. 2, pp. 448-474.

David, T. and Westerhuis, G. (2014), The Power of Corporate Networks: A Comparative and Historical Perspective, Routledge.

Davis, G.F. (1991), “Agents without principles? The spread of the poison pill through the intercorporate network.”, Administrative Science Quarterly, Vol. 36 No. 4, pp. 583-613.

Davis, G.F. (1993), "Who gets ahead in the market for corporate directors: the political economy of multiple board memberships.", Academy of Management Proceedings, Vol. 1993, Academy of Management Briarcliff Manor, NY 10510, pp. 202-206.

Detthamrong, U., Chancharat, N. and Vithessonthi, C. (2017), “Corporate governance, capital structure and firm performance: Evidence from Thailand", Research in International Business and Finance, Vol. 42, pp. 689-709. 
DiMaggio, P.J. and Powell, W.W. (1983), “The iron cage revisited: Institutional isomorphism and collective rationality in organizational fields", American Sociological Review, pp. $147-160$.

Doldor, E. (2017), “UK: The merits and shortcomings of a voluntary approach”, Gender Diversity in the Boardroom, Springer, pp. 13-44.

Drago, C. and Aliberti, L.A. (2019), "Interlocking Directorship Networks and Gender: A Bibliometric Analysis", in Paoloni, P. and Lombardi, R. (Eds.), Advances in Gender and Cultural Research in Business and Economics, Springer International Publishing, pp. $115-136$.

Dunn, P. (2012), “Breaking the boardroom gender barrier: the human capital of female corporate directors", Journal of Management \& Governance, Vol. 16 No. 4, pp. 557-570.

European Commission. (2012), "Proposal for a Directive of the European Parliament and of the Council on improving the gender balance among non-executive directors of companies listed on stock exchanges and related measures", European Commission, Brussels.

Fernández- Fernández, J.-L. (1999), "Ethics and the Board of Directors in Spain: The Olivencia Code of Good Governance", Journal of Business Ethics, Vol. 22 No. 3, pp. 233-247.

Fernandez, R.M. and Gould, R.V. (1994), “A dilemma of state power: Brokerage and influence in the national health policy domain”, American Journal of Sociology, Vol. 99 No. 6, pp. $1455-1491$.

Ferris, S.P., Jagannathan, M. and Pritchard, A.C. (2003), “Too busy to mind the business? Monitoring by directors with multiple board appointments", The Journal of Finance, Vol. 58 No. 3, pp. 1087-1111. 
Fich, E.M. and Shivdasani, A. (2012), “Are Busy Boards Effective Monitors?”, in Boubaker, S., Nguyen, B.D. and Nguyen, D.K. (Eds.), Corporate Governance: Recent Developments and New Trends, Springer, Berlin, Heidelberg, pp. 221-258.

Field, L., Lowry, M. and Mkrtchyan, A. (2013), “Are busy boards detrimental?”, Journal of Financial Economics, Vol. 109 No. 1, pp. 63-82.

Fligstein, N. and Brantley, P. (1992), "Bank control, owner control, or organizational dynamics: Who controls the large modern corporation?", American Journal of Sociology, Vol. 98 No. 2, pp. 280-307.

FRC. (2018), “The UK corporate governance code”, Financial Reporting Council, available at: www.frc. org.uk/getattachment/88bd8c45-50ea-4841-95b0-d2f4f48069a2/2018-UKCorpoate-Governance- Code-FINAL.pdf.

Garanina, T. and Muravyev, A. (2020), “The gender composition of corporate boards and firm performance: Evidence from Russia”, Emerging Markets Review, p. 100772.

Glass, C. and Cook, A. (2016), “Leading at the top: Understanding women's challenges above the glass ceiling", The Leadership Quarterly, Vol. 27 No. 1, pp. 51-63.

Gould, R.V. and Fernandez, R.M. (1989), "Structures of mediation: A formal approach to brokerage in transaction networks", Sociological Methodology, pp. 89-126.

Granovetter, M. (1985), “Economic Action and Social Structure: The Problem of Embeddedness", American Journal of Sociology, University of Chicago Press, Vol. 91 No. 3, pp. 481-510.

Green, C.P. and Homroy, S. (2018), "Female directors, board committees and firm performance", European Economic Review, Vol. 102, pp. 19-38.

Guest, P.M. (2009), "The impact of board size on firm performance: evidence from the UK”, The European Journal of Finance, Taylor \& Francis, Vol. 15 No. 4, pp. 385-404. 
Gujarati, D.N., Porter, D.C. and Gunasekar, S. (2012), Basic Econometrics, Tata McGraw-Hill Education.

Gulamhussen, M.A. and Santa, S.F. (2015), "Female directors in bank boardrooms and their influence on performance and risk-taking”, Global Finance Journal, Vol. 28, pp. 10-23.

Gulati, R. (1995), “Does familiarity breed trust? The implications of repeated ties for contractual choice in alliances", Academy of Management Journal, Vol. 38 No. 1, pp. 85-112.

Hamdan, A. (2018), "Board interlocking and firm performance: The role of foreign ownership in Saudi Arabia”, International Journal of Managerial Finance, Emerald Publishing Limited.

Harris, I.C. and Shimizu, K. (2004), “Too Busy To Serve? An Examination of the Influence of Overboarded Directors”, Journal of Management Studies, Vol. 41 No. 5, pp. 775-798.

Haunschild, P. and Beckman, C. (1998), "When do interlocks matter?: Alternate sources of information and interlock influence”, Administrative Science Quarterly, Vol. 43 No. 4, pp. $815-844$.

Haunschild, P.R. (1993), “Interorganizational Imitation: The Impact of Interlocks on Corporate Acquisition Activity”, Administrative Science Quarterly, Vol. 38 No. 4, pp. 564-592.

Hawaj, A.Y.A. and Buallay, A.M. (2021), “A worldwide sectorial analysis of sustainability reporting and its impact on firm performance", Journal of Sustainable Finance \& Investment, Taylor \& Francis, Vol. 0 No. 0, pp. 1-25.

Hawawini, G., Subramanian, V. and Verdin, P. (2003), "Is performance driven by industry-or firm-specific factors? A new look at the evidence", Strategic Management Journal, Vol. 24 No. 1, pp. 1-16.

Haynes, K.T. and Hillman, A. (2010), "The effect of board capital and CEO power on strategic change”, Strategic Management Journal, Vol. 31 No. 11, pp. 1145-1163. 
Heemskerk, E. and Fennema, M. (2009), "Network Dynamics of the Dutch Business Elite”, International Sociology, Vol. 24 No. 6, pp. 807-832.

Heemskerk, E.M., Fennema, M. and Carroll, W.K. (2016), “The global corporate elite after the financial crisis: evidence from the transnational network of interlocking directorates", Global Networks, Vol. 16 No. 1, pp. 68-88.

Hernández-Lara, A.B. and Gonzales-Bustos, J.P. (2018), “The impact of interlocking directorates on innovation: the effects of business and social ties", Management Decision, available at:https://doi.org/10.1108/MD-11-2017-1186.

Higgs, D. (2003), "Review of the role and effectiveness of nonexecutive directors", available at: www.dti.gov.uk/cld/non_execs_review.

Hillman, A.J., Cannella, A.A. and Harris, I.C. (2002), "Women and Racial Minorities in the Boardroom: How Do Directors Differ?”, Journal of Management, Vol. 28 No. 6, pp. 747763.

Hillman, A.J. and Dalziel, T. (2003), "Boards of directors and firm performance: Integrating agency and resource dependence perspectives", Academy of Management Review, Vol. 28 No. 3, pp. 383-396.

Huse, M. (2012), “The 'Golden Skirts': Lessons from Norway about Women on Corporate Boards of Directors", Diversity Quotas, Diverse Perspectives, Routledge.

Isidro, H. and Sobral, M. (2015), "The Effects of Women on Corporate Boards on Firm Value, Financial Performance, and Ethical and Social Compliance”, Journal of Business Ethics, Vol. 132 No. 1, pp. 1-19.

Jasny, L. and Lubell, M. (2015), “Two-mode brokerage in policy networks”, Social Networks, Vol. 41, pp. 36-47. 
Johanson, D. and Østergren, K. (2010), “The movement toward independent directors on boards: A comparative analysis of Sweden and the UK", Corporate Governance: An International Review, Vol. 18 No. 6, pp. 527-539.

Kaczmarek, S., Kimino, S. and Pye, A. (2014), "Interlocking directorships and firm performance in highly regulated sectors: the moderating impact of board diversity", Journal of Management \& Governance, Vol. 18 No. 2, pp. 347-372.

Kahneman, D., Slovic, S.P., Slovic, P. and Tversky, A. (1982), Judgment under Uncertainty: Heuristics and Biases, Cambridge university press.

King, A.A., Lenox, M.J. and Barnett, M.L. (2002), "Strategic responses to the reputation commons problem", Organizations, Policy and the Natural Environment: Institutional and Strategic Perspectives, Stanford University Press Stanford, CA, Vol. 43 No. 1, pp. $393-406$.

Kirsch, A. (2018), "The gender composition of corporate boards: A review and research agenda", The Leadership Quarterly, Vol. 29 No. 2, pp. 346-364.

Kroes, N. (2009), Europe-Good for Women and Good for Ireland, Speech.

Lang, J.R. and Lockhart, D.E. (1990), "Increased environmental uncertainty and changes in board linkage patterns", Academy of Management Journal, Vol. 33 No. 1, pp. 106-128.

Larcker, D.F. and Tayan, B. (2013), "Pioneering women on boards: Pathways of the first female directors", Rock Center for Corporate Governance at Stanford University Closer Look Series: Topics, Issues and Controversies in Corporate Governance and Leadership No. CGRP-35.

Lau, C.K. (2016), “How corporate derivatives use impact firm performance?”, Pacific-Basin Finance Journal, Vol. 40, pp. 102-114. 
Lenard, M.J., Yu, B., Anne York, E. and Wu, S. (2014), "Impact of board gender diversity on firm risk", Managerial Finance, Emerald Group Publishing Limited, Vol. 40 No. 8, pp. 787-803.

Lind, B.E., Tirado, M., Butts, C.T. and Petrescu-Prahova, M. (2008), “Brokerage roles in disaster response: organisational mediation in the wake of Hurricane Katrina", International Journal of Emergency Management, Vol. 5 No. 1-2, pp. 75-99.

Lorsch, J. and Young, J. (1990), "Pawns or potentates: The reality of America's corporate boards", Academy of Management Perspectives, Vol. 4 No. 4, pp. 85-87.

Lückerath-Rovers, M. (2013), “Women on boards and firm performance”, Journal of Management \& Governance, Vol. 17 No. 2, pp. 491-509.

Marinova, J., Plantenga, J. and Remery, C. (2016), “Gender diversity and firm performance: evidence from Dutch and Danish boardrooms", The International Journal of Human Resource Management, Vol. 27 No. 15, pp. 1777-1790.

Mashayekhi, B. and Bazaz, M.S. (2008), "Corporate Governance and Firm Performance in Iran”, Journal of Contemporary Accounting \& Economics, Vol. 4 No. 2, pp. 156-172.

Mastella, M., Vancin, D., Perlin, M. and Kirch, G. (2021), "Board gender diversity: performance and risk of Brazilian firms", Gender in Management: An International Journal, Emerald Publishing Limited.

Mazzotta, R., Bronzetti, G. and Baldini, M.A. (2017), "Does board diversity affect firm performance? Evidence from the Italian financial sector", International Journal of Business Governance and Ethics, Vol. 12 No. 1, pp. 65-89.

McKinsey. (2007), Women Matter: Gender Diversity, a Corporate Performance Driver, McKinsey. 
McWilliams, A. and Siegel, D. (2000), “Corporate social responsibility and financial performance: correlation or misspecification?", Strategic Management Journal, Vol. 21 No. 5, pp. 603-609.

Mensi-Klarbach, H., Leixnering, S. and Schiffinger, M. (2019), "The carrot or the stick: Selfregulation for gender-diverse boards via codes of good governance", Journal of Business Ethics, pp. 1-17.

Mintz, B.A. and Schwartz, M. (1985), The Power Structure of American Business, University of Chicago Press.

Mizruchi, M.S. (1989), "Similarity of political behavior among large American corporations”, American Journal of Sociology, Vol. 95 No. 2, pp. 401-424.

Mizruchi, M.S. (1992), The Structure of Corporate Political Action: Interfirm Relations and Their Consequences, Harvard University Press.

Mizruchi, M.S. (1996), "What Do Interlocks Do? An Analysis, Critique, and Assessment of Research on Interlocking Directorates”, Annual Review of Sociology, Vol. 22, pp. 271298.

Mizruchi, M.S. and Stearns, L.B. (1988), “A Longitudinal Study of the Formation of Interlocking Directorates", Administrative Science Quarterly, Vol. 33 No. 2, pp. 194-210.

Mokadem, W. and Muwafak, B.M. (2020), "The Difference of the Theoretical Approach of Corporate Social Responsibility Between the European Union and United States of America", International Journal of Business Ethics and Governance, Vol. 3 No. 1, pp. 113.

Moura-Leite, R.C., Padgett, R.C. and Galan, J.I. (2012), “Is social responsibility driven by industry or firm-specific factors?”, Management Decision, Emerald Group Publishing Limited, Vol. 50 No. 7, pp. 1200-1221. 
Nguyen, P., Rahman, N., Tong, A. and Zhao, R. (2016), "Board size and firm value: evidence from Australia”, Journal of Management \& Governance, Springer, Vol. 20 No. 4, pp. $851-873$.

Nguyen, T.H.H., Ntim, C.G. and Malagila, J.K. (2020), “Women on corporate boards and corporate financial and non-financial performance: A systematic literature review and future research agenda", International Review of Financial Analysis, Vol. 71, p. 101554.

Nicholson, G.J. and Kiel, G.C. (2007), “Can directors impact performance? A case-based test of three theories of corporate governance", Corporate Governance: An International Review, Vol. 15 No. 4, pp. 585-608.

O’Hagan, S. and Green, M. (2004), “Corporate knowledge transfer via interlocking directorates: a network analysis approach", Geoforum, Vol. 35 No. 1, pp. 127-139.

O’Hagan, S.B. (2017), “An exploration of gender, interlocking directorates, and corporate performance", International Journal of Gender and Entrepreneurship, Vol. 9 No. 3, pp. $269-282$.

Pennings, J.M. (1980), Interlocking Directorates: Origins and Consequences of Connections among Organizations' Board of Directors, Jossey-Bass.

Petersen, V. (2016), “Interlocking Directorates in the European Union: An Argument for Their Restriction”, European Business Law Review, Vol. 27 No. 6, pp. 821-864.

Pfeffer, J. and Salancik, G.R. (1978), “The external control of organizations: A resource dependence approach", NY: Harper and Row Publishers.

Piscopo, J.M. and Clark Muntean, S. (2018), “Corporate quotas and symbolic politics in advanced democracies”, Journal of Women, Politics \& Policy, Taylor \& Francis, Vol. 39 No. 3, pp. 285-309. 
Powell, T.C. (1996), “How Much Does Industry Matter? An Alternative Empirical Test”, Strategic Management Journal, Vol. 17 No. 4, pp. 323-334.

Rebérioux, A. and Roudaut, G. (2019), “The Role of Rookie Female Directors in a Post-Quota Period: Gender Inequalities within French Boards", Industrial Relations: A Journal of Economy and Society, Vol. 58 No. 3, pp. 423-483.

Richardson, R.J. (1987), “Directorship interlocks and corporate profitability”, Administrative Science Quarterly, pp. 367-386.

Rigolini, A., Gabaldon, P. and Le Bruyn Goldeng, E. (2021), “CEO succession with gender change in troubled companies: The effect of a new woman CEO on firm risk and firm risk perceived”, Scandinavian Journal of Management, Vol. 37 No. 1, p. 101138.

Ruigrok, W., Peck, S. and Tacheva, S. (2007), "Nationality and gender diversity on Swiss corporate boards", Corporate Governance- an International Review, Vol. 15 No. 4, pp. $546-557$.

Ryan, M.K. and Haslam, S.A. (2007), “The Glass Cliff: Exploring the Dynamics Surrounding the Appointment of Women to Precarious Leadership Positions", The Academy of Management Review, Academy of Management, Vol. 32 No. 2, pp. 549-572.

Sanders, W.G. and Tuschke, A. (2007), "The adoption of institutionally contested organizational practices: The emergence of stock option pay in Germany", Academy of Management Journal, Vol. 50 No. 1, pp. 33-56.

Sarabi, Y. and Smith, M. (2021), "Busy female directors: an exploratory analysis of the impact of quotas and interest groups", Gender in Management: An International Journal, Emerald Publishing Limited, Vol. 36 No. 3, pp. 368-385.

Seierstad, C. and Huse, M. (2017), “Gender Quotas on Corporate Boards in Norway: Ten Years Later and Lessons Learned”, in Seierstad, C., Gabaldon, P. and Mensi-Klarbach, H. 
(Eds.), Gender Diversity in the Boardroom: Volume 1: The Use of Different Quota Regulations, Springer International Publishing, Cham, pp. 11-45.

Seierstad, C. and Opsahl, T. (2011), "For the few not the many? The effects of affirmative action on presence, prominence, and social capital of women directors in Norway", Scandinavian Journal of Management, Vol. 27 No. 1, pp. 44-54.

Seierstad, C., Warner-Søderholm, G., Torchia, M. and Huse, M. (2017), “Increasing the Number of Women on Boards: The Role of Actors and Processes", Journal of Business Ethics, Vol. 141 No. 2, pp. 289-315.

Selznick, P. (2011), Leadership in Administration: A Sociological Interpretation, Quid Pro Books.

Sheard, P. (1993), The Economics of Interlocking Shareholding in Japan, Center for Economic Policy Research, Stanford University.

Short, J.C., Ketchen, D.J., Palmer, T.B. and Hult, G.T.M. (2007), "Firm, strategic group, and industry influences on performance", Strategic Management Journal, Vol. 28 No. 2, pp. $147-167$.

Shropshire, C. (2010), "The role of the interlocking director and board receptivity in the diffusion of practices", Academy of Management Review, Academy of Management Briarcliff Manor, NY, Vol. 35 No. 2, pp. 246-264.

Singh, V., Terjesen, S. and Vinnicombe, S. (2008), "Newly appointed directors in the boardroom:: How do women and men differ?”, European Management Journal, Vol. 26 No. 1, pp. $48-58$.

Singh, V. and Vinnicombe, S. (2004), "Why so few women directors in top UK boardrooms? Evidence and theoretical explanations", Corporate Governance: An International Review, Vol. 12 No. 4, pp. 479-488. 
Sisaye, S. (2021), "The influence of non-governmental organizations (NGOs) on the development of voluntary sustainability accounting reporting rules", Journal of Business and Socio-Economic Development, Vol. ahead-of-print No. ahead-of-print, available at:https://doi.org/10.1108/JBSED-02-2021-0017.

Smith, M. (2019), CompaniesHouse: Extract \& Process Companies House Data in R, available at: https://github.com/MatthewSmith430/CompaniesHouse.

Smith, M. and Sarabi, Y. (2021a), “What do interlocks do' revisited - a bibliometric analysis”, Management Research Review, Emerald Publishing Limited, Vol. 44 No. 4, pp. 642-659.

Smith, M. and Sarabi, Y. (2021b), "UK trading patterns within and between regions in the automotive sector-A network analysis", The World Economy, Vol. 44 No. 2, pp. 510529.

Smith, N., Smith, V. and Verner, M. (2006), "Do women in top management affect firm performance? A panel study of 2,500 Danish firms", International Journal of Productivity and Performance Management, Vol. 55 No. 7, pp. 569-593.

Stokman, F.N., Van der Knoop, J. and Wasseur, F.W. (1988), "Interlocks in the Netherlands: Stability and careers in the period 1960-1980", Social Networks, Vol. 10 No. 2, pp. 183208.

Strøm, R.Ø. (2015), “Gender discrimination before mandated quotas? Evidence from Norway: 1989-2002”, Scandinavian Journal of Management, Vol. 31 No. 3, pp. 303-315.

Tyson, L. (2003), “The Tyson report on the recruitment and development of nonexecutive directors", available at: www.london.edu/tysonreport.

Useem, M. (1982), “Classwide Rationality in the Politics of Managers and Directors of Large Corporations in the United States and Great Britain”, Administrative Science Quarterly, 
[Sage Publications, Inc., Johnson Graduate School of Management, Cornell University], Vol. 27 No. 2, pp. 199-226.

Useem, M. (1986), The Inner Circle: Large Corporations and the Rise of Business Political Activity in the US and UK, Oxford University Press.

Watson, J. (2007), "Modeling the relationship between networking and firm performance", Journal of Business Venturing, Vol. 22 No. 6, pp. 852-874.

Weick, K.E. (1995), Sensemaking in Organizations, Vol. 3, Sage.

Yermack, D. (1996), "Higher market valuation of companies with a small board of directors", Journal of Financial Economics, Elsevier, Vol. 40 No. 2, pp. 185-211.

You, J., Terjesen, S. and Bilimoria, D. (2018), "Women in the Upper Echelons: Women on Corporate Boards and in Top Management Teams", Oxford Research Encyclopedia of Business and Management, available at:https://doi.org/10.1093/acrefore/9780190224851.013.46.

Zabri, S.M., Ahmad, K. and Wah, K.K. (2016), "Corporate governance practices and firm performance: Evidence from top 100 public listed companies in Malaysia", Procedia Economics and Finance, Elsevier, Vol. 35, pp. 287-296.

Zajac, E.J. (1988), “Interlocking directorates as an interorganizational strategy: A test of critical assumptions", Academy of Management Journal, Vol. 31 No. 2, pp. 428-438.

Zalata, A.M., Ntim, C., Aboud, A. and Gyapong, E. (2019), "Female CEOs and Core Earnings Quality: New Evidence on the Ethics Versus Risk-Aversion Puzzle”, Journal of Business Ethics, Vol. 160 No. 2, pp. 515-534. 
Gould-Fernandez brokerage roles (1-mode network)

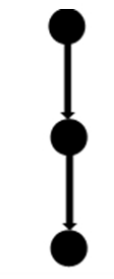

Coordinator

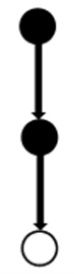

Representative

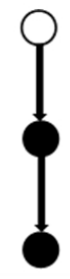

Gatekeeper

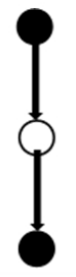

Itinerant

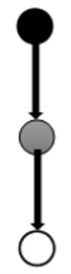

Liaison

Figure 1 Gould-Fernandez brokerage role (1-mode network) $338 \times 190 \mathrm{~mm}(96 \times 96 \mathrm{DPI})$ 
Two-mode variant of GF roles

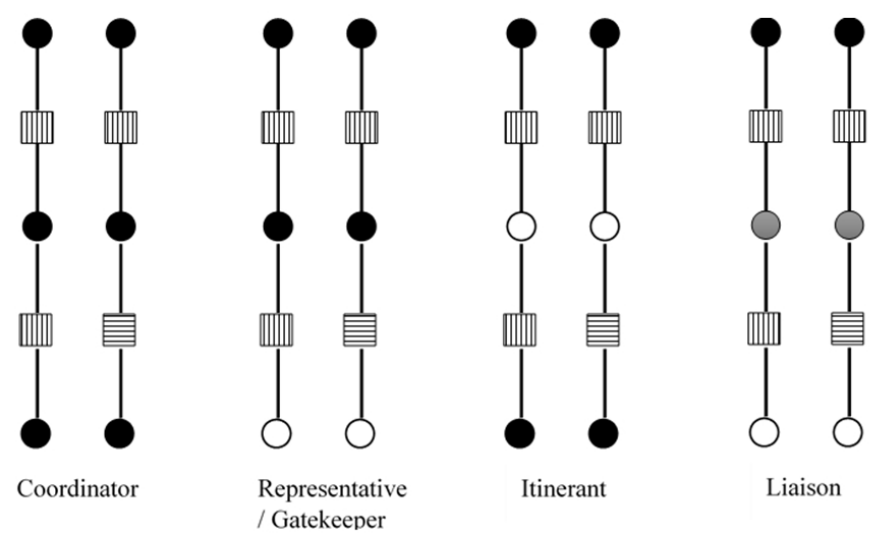

Figure 2 Two-mode variant of GF roles $338 \times 190 \mathrm{~mm}(96 \times 96 \mathrm{DPI})$ 
Brokered vs non-brokered chain

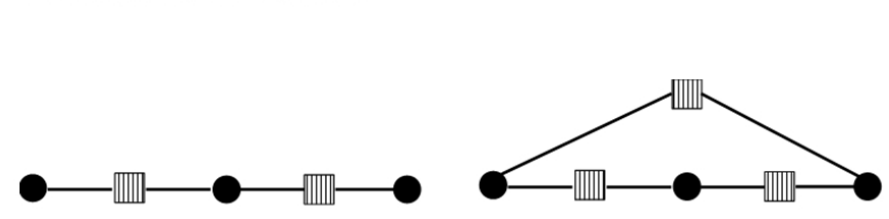

Brokered chain

Non- brokered chain

Figure 3 Brokered vs non-brokered chain $338 \times 190 \mathrm{~mm}(96 \times 96 \mathrm{DPI})$ 
Number of firms from each sector holding a two-mode GF role

2010

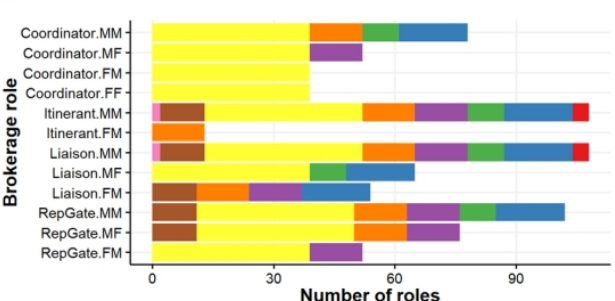

2014

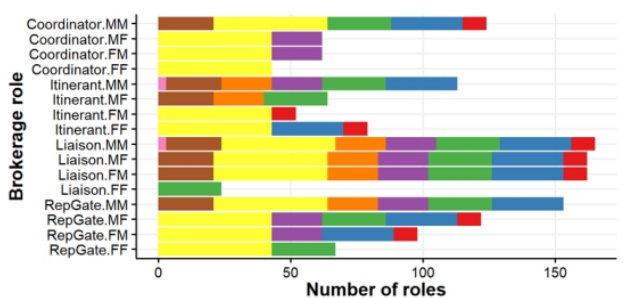

2018

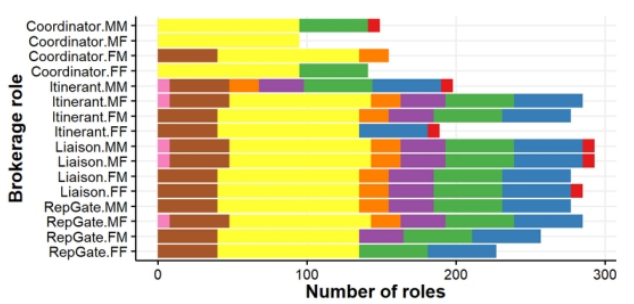

Sectors

Mining \& Construction

Manufacturing - Textile, Paper, Wood \& Chemical

Manufacturing - Rubber, Metal Industrial, Eletronics \& Transportation

Transportation, Communications, Electric, Gas \& Sanitary service

Wholesale \& Retail Trade

inance, Insurance, \& Real Estate

Services - Personal \& Supporting Business

Services - Health, Legal \& Social

Figure 4 Number of firms from each sector holding a two-mode GF role $304 \times 177 m m(150 \times 150$ DPI $)$ 


\section{TABLE 1}

Table 1 Firm level descriptive statistics

\begin{tabular}{lccccc}
\hline Variable & N & Mean & Std. dev. & Min. & Max. \\
\hline $\begin{array}{l}\text { Return on Capital Employed } \\
\text { (ROCE) }\end{array}$ & 2,169 & 15.928 & 27.715 & -114.74 & 799.75 \\
\hline Board Size & 2,169 & 9.368 & 2.508 & 4 & 20 \\
\hline Assets (log) & 2,169 & 15.432 & 1.775 & 10.879 & 21.606 \\
\hline Number of Employees (log) & 2,169 & 9.006 & 1.863 & 1.386 & 13.382
\end{tabular}


TABLE 2

Table 2 Proportion of firms belonging to each sector

\begin{tabular}{lr}
\hline Sector & Proportion \\
\hline Mining \& Construction & 6.64 \\
\hline Manufacturing - Textile, Paper, Wood \& & 13.28 \\
\hline Manufacturing - Rubber, Metal, Industrial, & 9.13 \\
Electronics \& Transportation & \\
\hline Transportation, Communications, Electric, & 10.79 \\
Gas \& Sanitary Services & \\
\hline Wholesale \& Retail Trade & 10.79 \\
\hline Finance, Insurance \& Real Estate & 33.20 \\
\hline Services - Personal \& Supporting Business & 11.20 \\
\hline Services - Health, Legal \& Social & 4.98 \\
\hline
\end{tabular}




\section{TABLE 3}

\section{Table 3 Model estimates (ROCE)}

\begin{tabular}{|c|c|c|c|c|}
\hline & RepGate & Itinerant & Coordinator & Liaison \\
\hline \multirow[t]{2}{*}{ Number of Employees (log) } & -0.5831 & -0.5698 & -0.5915 & -0.5405 \\
\hline & $(0.4463)$ & $(0.4459)$ & $(0.4467)$ & $(0.4419)$ \\
\hline \multirow[t]{2}{*}{ Total Assets (Log) } & $-1.8736 * * *$ & $-1.8423 * * *$ & $-1.8452 * * *$ & $-1.9019 * * *$ \\
\hline & $(0.5121)$ & $(0.5119)$ & $(0.5117)$ & $(0.5058)$ \\
\hline \multirow[t]{2}{*}{ Board Size } & 0.0065 & 0.0274 & 0.0154 & -0.0133 \\
\hline & $(0.2904)$ & $(0.2892)$ & $(0.2890)$ & $(0.2865)$ \\
\hline \multirow{2}{*}{$\begin{array}{l}\text { Sector: Manufacturing - Textile, Paper, } \\
\text { Wood \& Chemical }\end{array}$} & 5.9351 & 6.1312 & 5.9899 & 4.8247 \\
\hline & $(3.1582)$ & $(3.1557)$ & $(3.1534)$ & $(3.1341)$ \\
\hline \multirow{2}{*}{$\begin{array}{l}\text { Sector: Manufacturing - Rubber, } \\
\text { Metal, Industrial, Electronics \& } \\
\text { Transportation }\end{array}$} & 0.4892 & 0.7745 & 0.4399 & -0.2524 \\
\hline & $(3.4093)$ & $(3.3916)$ & $(3.3898)$ & (3.3563) \\
\hline \multirow{3}{*}{$\begin{array}{l}\text { Sector: } \\
\text { Communications, Electric, Gas \& } \\
\text { Sanitary Services }\end{array}$} & 2.5915 & 2.9512 & 2.6413 & 2.9823 \\
\hline & & & & \\
\hline & $(3.2668)$ & $(3.2586)$ & $(3.2512)$ & $(3.2197)$ \\
\hline \multirow[t]{2}{*}{ Sector: Wholesale \& Retail Trade } & $6.7522 *$ & $7.0215^{*}$ & $6.8259^{*}$ & $7.0829 *$ \\
\hline & $(3.3432)$ & $(3.3474)$ & $(3.3421)$ & $(3.3085)$ \\
\hline \multirow{2}{*}{$\begin{array}{l}\text { Sector: Finance, Insurance \& Real } \\
\text { Estate }\end{array}$} & 2.9116 & 2.9616 & 2.7179 & 3.5362 \\
\hline & $(2.8270)$ & $(2.8175)$ & (2.8347) & (2.7862) \\
\hline \multirow{2}{*}{$\begin{array}{l}\text { Sector: Services - } \\
\text { Supporting Business }\end{array}$} & $10.0990 * *$ & $10.3501^{* *}$ & $10.1663^{* *}$ & $10.2913 * *$ \\
\hline & $(3.2847)$ & $(3.2845)$ & $(3.2816)$ & $(3.2589)$ \\
\hline \multirow[t]{2}{*}{$\begin{array}{l}\text { Sector: Services - Health, Legal \& } \\
\text { Social }\end{array}$} & -1.7968 & -1.6110 & -1.7405 & -1.0787 \\
\hline & $(3.9861)$ & (3.9886) & $(3.9859)$ & $(3.9422)$ \\
\hline \multirow[t]{2}{*}{ Female-Male Role (lag 1) } & -0.1885 & -5.2031 & -0.0020 & $6.5136^{* * *}$ \\
\hline & $(1.9614)$ & $(5.2846)$ & $(1.7761)$ & $(1.7024)$ \\
\hline \multirow[t]{2}{*}{ Male-Female Role (lag 1) } & -0.0222 & -2.9774 & 0.5789 & $10.2540 * * *$ \\
\hline & $(2.3787)$ & $(9.7228)$ & $(2.8994)$ & $(2.0068)$ \\
\hline \multirow[t]{2}{*}{ Male-Male Role (lag 1) } & 0.1266 & -2.5189 & 1.3056 & $-2.0586^{* *}$ \\
\hline & $(0.9185)$ & $(2.6232)$ & $(1.7218)$ & $(0.7954)$ \\
\hline \multirow[t]{2}{*}{ Female-Female Role (lag 1) } & 2.3184 & 3.8080 & 2.3322 & $-10.2182 *$ \\
\hline & $(4.8957)$ & $(7.9217)$ & $(4.8031)$ & $(4.0921)$ \\
\hline$\overline{\mathrm{R}^{2}}$ & 0.0337 & 0.0346 & 0.0340 & 0.0560 \\
\hline Adj. $R^{2}$ & 0.0230 & 0.0240 & 0.0233 & 0.0456 \\
\hline Num. obs. & 1928 & 1928 & 1928 & 1928 \\
\hline
\end{tabular}

$* * * \mathrm{p}<0.001 ; * * \mathrm{p}<0.01 ; * \mathrm{p}<0.05$ 


\section{TABLE 4}

\section{Table 4 Model estimates (ROE)}

\begin{tabular}{|c|c|c|c|c|}
\hline & RepGate & Itinerant & Coordinator & Liaison \\
\hline Number of Employees (log) & $\begin{array}{l}1.6658^{*} \\
(0.7088)\end{array}$ & $\begin{array}{l}1.6675^{*} \\
(0.7083)\end{array}$ & $\begin{array}{l}1.6428^{*} \\
(0.7100)\end{array}$ & $\begin{array}{l}1.6728^{*} \\
(0.7098)\end{array}$ \\
\hline Total Assets (Log) & $\begin{array}{l}-3.2117 * * * \\
(0.8133)\end{array}$ & $\begin{array}{l}-3.1506^{* * *} \\
(0.8130)\end{array}$ & $\begin{array}{l}-3.1919 * * * \\
(0.8132)\end{array}$ & $\begin{array}{l}-3.1245^{* * *} \\
(0.8124)\end{array}$ \\
\hline Board Size & $\begin{array}{l}0.6529 \\
(0.4613)\end{array}$ & $\begin{array}{l}0.6681 \\
(0.4593)\end{array}$ & $\begin{array}{l}0.6695 \\
(0.4594)\end{array}$ & $\begin{array}{l}0.7359 \\
(0.4603)\end{array}$ \\
\hline $\begin{array}{l}\text { Sector: Manufacturing - Textile, } \\
\text { Paper, Wood \& Chemical }\end{array}$ & $(5.0160)$ & $(5.0122)$ & $24.9050 * * *$ & $(5.0342)$ \\
\hline $\begin{array}{l}\text { Sector: Manufacturing - Rubber, } \\
\text { Metal, Industrial, Electronics \& } \\
\text { Transportation }\end{array}$ & 8.7472 & 8.6918 & 8.4463 & 9.0859 \\
\hline $\begin{array}{l}\text { Sector: Transportation, } \\
\text { Communications, Electric, Gas \& } \\
\text { Sanitary Services }\end{array}$ & $\begin{array}{l}(5.4149) \\
18.5488^{* * *}\end{array}$ & $\begin{array}{l}(5.3868) \\
19.4510^{* * *}\end{array}$ & $\begin{array}{l}(5.3872) \\
18.8222 * * *\end{array}$ & $\begin{array}{l}(5.3912) \\
19.3797 * * *\end{array}$ \\
\hline Sector: Wholesale \& Retail Trade & $\begin{array}{l}(5.1885) \\
16.2487 * * \\
(5.3099)\end{array}$ & $\begin{array}{l}(5.1756) \\
16.5417 * * \\
(5.3166)\end{array}$ & $\begin{array}{l}(5.1670) \\
16.3552^{* *} \\
(5.3114)\end{array}$ & $\begin{array}{l}(5.1718) \\
16.7613^{* *} \\
(5.3144)\end{array}$ \\
\hline $\begin{array}{l}\text { Sector: Finance, Insurance \& Real } \\
\text { Estate }\end{array}$ & $\begin{array}{l}8.7299 \\
(4.4899)\end{array}$ & $\begin{array}{l}8.6829 \\
(4.4750)\end{array}$ & $\begin{array}{l}8.6646 \\
(4.5050)\end{array}$ & $\begin{array}{l}8.7782 * \\
(4.4754)\end{array}$ \\
\hline $\begin{array}{l}\text { Sector: Services - Personal \& } \\
\text { Supporting Business }\end{array}$ & $\begin{array}{l}12.1726^{*} \\
(5.2169)\end{array}$ & $\begin{array}{l}12.7491^{*} \\
(5.2168)\end{array}$ & $\begin{array}{l}12.3305 * \\
(5.2153)\end{array}$ & $\begin{array}{l}13.1966^{*} \\
(5.2347)\end{array}$ \\
\hline $\begin{array}{l}\text { Sector: Services - Health, Legal \& } \\
\text { Social }\end{array}$ & $\begin{array}{l}7.3704 \\
(6.3310)\end{array}$ & $\begin{array}{l}7.8716 \\
(6.3351)\end{array}$ & $\begin{array}{l}7.4223 \\
(6.3346)\end{array}$ & $\begin{array}{l}7.6373 \\
(6.3323)\end{array}$ \\
\hline Female-Male Role (lag 1) & $\begin{array}{l}4.4348 \\
(3.1151)\end{array}$ & $\begin{array}{l}-0.1146 \\
(8.3935)\end{array}$ & $\begin{array}{l}-0.6768 \\
(2.8226)\end{array}$ & $\begin{array}{l}-0.5304 \\
(2.7346)\end{array}$ \\
\hline Male-Female Role (lag 1) & $\begin{array}{l}-0.4948 \\
(3.7780)\end{array}$ & $\begin{array}{l}-1.6826 \\
(15.4426)\end{array}$ & $\begin{array}{l}1.5154 \\
(4.6078)\end{array}$ & $\begin{array}{l}-0.9577 \\
(3.2235)\end{array}$ \\
\hline Male-Male Role (lag 1) & $\begin{array}{l}-0.9525 \\
(1.4589)\end{array}$ & $\begin{array}{l}-8.3024 * \\
(4.1664)\end{array}$ & $\begin{array}{l}0.9877 \\
(2.7364)\end{array}$ & $\begin{array}{l}-2.0742 \\
(1.2777)\end{array}$ \\
\hline Female-Female Role (lag 1) & $\begin{array}{l}-1.5981 \\
(7.7755)\end{array}$ & $\begin{array}{l}1.7493 \\
(12.5819)\end{array}$ & $\begin{array}{l}2.9123 \\
(7.6332)\end{array}$ & $\begin{array}{l}-2.1090 \\
(6.5730)\end{array}$ \\
\hline $\mathrm{R}^{2}$ & 0.0385 & 0.0394 & 0.0376 & 0.0392 \\
\hline Adj. $R^{2}$ & 0.0279 & 0.0288 & 0.0270 & 0.0286 \\
\hline Num. obs. & 1928 & 1928 & 1928 & 1928 \\
\hline
\end{tabular}

$* * * \mathrm{p}<0.001 ; * * \mathrm{p}<0.01 ; * \mathrm{p}<0.05$ 